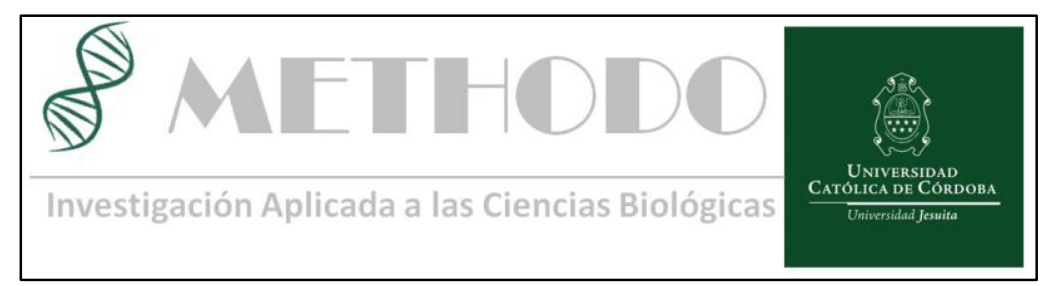

\title{
Hipertensión endocraneana idiopática: respuesta al tratamiento Topiramato vs Acetazolamida
}

\section{Endocranial idiopathic hypertension: response to treatment Topiramate vs. Acetazolamide}

\author{
Vergara $\mathrm{G}^{1-2-3}$, Vaudagna $\mathrm{P}^{1-2}$, Martinez $\mathrm{A}^{1-2}$, Paviolo $\mathrm{M}^{1-2}$, Miculan $\mathrm{J}^{1-2}$, Linzoain, $\mathrm{J}^{1}$, Sfaello $\mathrm{Z}^{1}$, \\ SfaelloI ${ }^{1-2}$
}

\section{Introducción:}

El término pseudotumorcerebri se reserva para denominar aquellas hipertensiones endocraneanas (HE) que clínicamente asemejan la existencia de un tumor cerebral, debido a la alteración de la circulación del líquido cefalorraquídeo (LCR). ${ }^{1-2}$ Para su diagnóstico se describen los criterios de Dandy-Smith. ${ }^{2-3}$

Tabla 1. Criterios de Dandy-Smith

Tabla I. Criterios diagnósticos de $\mathrm{HICl}$.

1. Si existen sintomas, éstos se deben a la hipertensión intracraneal o al papiledema.

2. Si existen signos, éstos se deben a la hipertensión intracraneal o al papiledema.

3. La elevación de la presión intracraneal debe ser medida en decúbito lateral.

4. La composición del LCR debe ser normal

5. No existen evidencias de hidrocefalia, masa estructural o lesión vascular en RM o TC con contraste, en los pacientes habituales, o en RM con estudio venoso en el resto de los pacientes.

6. No se identifican otras causas de hipertensión intracraneal.

\section{Objetivos:}

\section{Objetivo Primario:}

Determinar el beneficio del uso de Azetazolamida (ACZ) o Topiramato (TPM) en el tratamiento de la hipertensión endocraneana idiopática

\section{Objetivos Secundarios:}

Uso de Presión de apertura como parámetro indicador para uso de ACZ o TPM.

\section{Materiales y métodos:}

Tipo de estudio: Descriptivo Retrospectivo Observacional.

Los datos recabados fueron sometidos a evaluación en el software R-medic mediante el uso método estadístico de Chi Cuadrado y Diferencia de Proporciones.

Se obtuvo un total de 5 pacientes por que concurrieron a consultorio con diagnóstico de HEI mediante el uso de criterios de Dandy-Smith en el periodo 2013- 2017.

Se realizó a todos los pacientes:

RMc s/contraste

Fondo de ojo

Punción Lumbar con medición de presión de apertura.

Criterios de Inclusión:

Pacientes pediátricos (menores a 16 años) que consultan por sintomatología compatible según criterios de Dandy-Smith durante los 2013-2017 en instituto CETES.

Utilización de FO y RMc como métodos diagnósticos.

Presión de apertura $>25 \mathrm{mmHg}$

Criterios de Exclusión: Hipertensión Endocraneana Asociada a lesión ya sea de carácter isquémico, tumoral o secuelar. 


\section{Resultados:}

La media de seguimiento fue de 11 meses, con un rango entre 6-12 meses

Se estudiaron 5 pacientes con diagnóstico de Hipertensión Endocraneana Idiopática.

Del total de los pacientes $5(100 \%)$ tenían F.O patológico y como síntoma cardinal cefalea, 2 (40\%) además vómitos.

$3(60 \%)$ fue tratado con Topiramato (TPM) mientras que $2(40 \%)$ recibió acetazolamida (ACZ), ambos sin complicaciones $(\mathrm{p}=0,07)$

Del total de los pacientes $3(60 \%)$ presento presión de apertura menor de $40 \mathrm{mmHg}$ mientras que en los restantes $2(40 \%)$ fue mayor a $40 \mathrm{mmHg}$.

De estos últimos el 1 paciente recibió TPM y 1 paciente ACZ.

Dos pacientes (40\%) presentaron en el seguimiento una recaída sintomática, al intentar descender la medicación.

No se pudo definir como parámetro de decisión la presión de apertura en del uso de uno u otro medicamento ya que al evaluar el uso de TPM y ACZ en pacientes con presión de apertura mayor a $41 \mathrm{mmHg}$ solo se detallaron 2 pacientes cada uno tratado con un medicamento de los anteriormente descriptos. (Chi cuadrado $\mathrm{p}=0.44$ )

Ninguno de los pacientes tratados requirió otro tratamiento complementario como PL seriadas o válvula de derivación ventrículo peritoneal.

\section{Conclusión:}

No se logró determinar beneficio en el uso de un medicamento sobre otro en el tratamiento de la hipertensión endocraneana idiopática $(\mathrm{p}=0,07)$, pese al tamaño muestral, el cual podría ser un limitante. Coincidentemente con la literatura sigue sin haber evidencia suficiente.

No existe un algoritmo de consenso en cuanto al correcto manejo terapéutico y farmacológico de esta entidad.

El uso de TPM o ACZ no condiciona la posterior aparición de complicaciones $(\mathrm{p}=0.45)$

El estudio oftalmológico es esencial para diagnóstico y seguimiento.

No se pudo establecer correlación entre el valor obtenido en la medición de la resión de apertura y el tratamiento instaurado.

\section{Introduction:}

The term Pseudotumor cerebri is reserved for those endocranial hypertensio $(\mathrm{EH})$ that resemble clinically the existence of a brain tumor, due to alteration of the circulation of the cerebrospinal fluid (CSF). Classically, the Dandy-Smith criteria for diagnosis are described.Type of study Descriptive observational.

\section{Objective:}

\section{Primary Objective:}

To determine the benefit of the use of Azetazolamide (ACZ) or Topiramate (TPM) in the treatment of idiopathic endocranial hypertension Secondary Objectives:

Use of Opening Pressure as indicator parameter for use of ACZ or TPM.

\section{Materials and methods:}

Observed patients(N:5) per clinic with diagnosis of EIH by criteria of Dandy-Smith in the period 20132017.

I was performed in all patients:

RMNC s/contrast

Fundus oculi

Lumbar puncture + opening pressure.

\section{Results:}

Of the total of patients (5) $100 \%$ had F.O pathological and as cardinal symptom headache, and $40 \%$ also vomiting.

The mean follow-up was 11 months

$60 \%$ of the patients was treated with topiramate (TPM) while $40 \%$ received acetazolamide (ACZ), both without complications.

Of the total of patients $60 \%$ presented less than 40 opening pressure $\mathrm{mmHg}$, while that in the remaining $40 \%$ was greater than $40 \mathrm{mmHg}$, of which 50\% received TPM and 50\% ACZ.

$40 \%$ presented in tracking a symptomatic relapse, trying to get off the medication.

None of the treated patients required other adjunctive therapy such as serial PL or ventricleperitoneal shunt.

\section{Conclusions:}

It was not possible to determine benefit in the use of one drug over another in the treatment of idiopathic intracranial hypertension $(p=0.07)$, despite the sample size, which could be a limitation. Coincidentally with the literature there is still not enough evidence.

There is no consensus algorithm regarding the correct therapeutic and pharmacological management of this entity.

The use of TPM or ACZ does not condition the subsequent appearance of complications $(p=0.45)$ 
The ophthalmological study is essential for diagnosis and follow-up.

No correlation could be established between the value obtained in the measurement of the opening ression and the treatment established.

\section{Bibliografía:}

1. 1. Monge Galindo L, Fernando Martínez R, Fuertes Rodrigo C, Fustero de Miguel D,PueyoRoyo V, GarcíaIñiguez JP, López-Pisón J, Peña-Segura JL Idiopathic intracranial hypertension: Experience over 25 years and a management protocol an Pediatr (Barc). 2017;87(2):78-86

2. MosqueraGorostidi A, IridoyZulet M, Azcona Ganuza G, GemberoEsarte E, Yoldi Petri ME, Aguilera Albesa S. Pseudotumourcerebri in children: Aetiology, clinical features, and progression. Neurología $2017 \quad$ S02134853(16)30244-4. Doi: 10.1016/j.nrl.2016

.11 .003 .

3.Monge Galindo L, Pérez Delgado R, LópezPisón J, Olloqui-Escalona A, García Íñiguez JP, Ruiz del Olmo Izuzquiza I, Peña-Segura JL. Benign intracranial hypertension: Experience over 18 years an Pediatr (Barc). 2009;71(5):400-406

\section{Palabras claves:}

Hipertensión Endocraneana, Dandy-Smith, Topiramato, Azetazolamida

\section{Keywords:}

Endocraneal Hipertensión, Dandy-Smith, Topiramate, Azetazolamide

1 Servicio de Neurología Infantil, Instituto de Neurología Infantojuvenil, cCLil, CETES. Córdoba

2 Servicio de Neurología Infantil Clínica Universitaria Reina Fabiola. Córdoba. Argentina ${ }^{3}$ glen86vergara@gmail.com

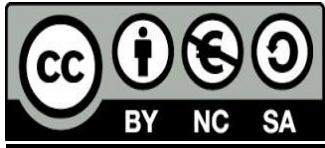

